\title{
Pengaruh Kelas Ibu Hamil Terhadap Tingkat Pengetahuan Ibu Hamil Tentang Tanda Bahaya Kehamilan di Wilayah Kerja Puskesmas Banyumulek
}

\author{
Ziadatul Munawarah $^{1 *}$ dan Nurul Hidayati ${ }^{1}$ \\ ${ }^{1}$ Jurusan Ilmu Kebidanan, Universitas Nahdlatul Wathan, Mataram, Indonesia \\ *Email : ziadatulmunawarah@gmail.com
}

\begin{abstract}
Abstrak : Berdasarkan pengamatan sementara bahwa peneliti telah melakukan pengamatan di puskesmas banyumulek. Dari 10 ibu hamil yang memeriksa kehamilannya hanya 4 orang yang mengetahui tanda-tanda bahaya kehamilan, peneliti menyimpulkan bahwa masih banyak ibu hamil yang belum mengetahui tanda-tanda bahaya kehamilan sehingga peneliti tertarik untuk meneliti tingkat pengetahuan ibu hamil tentang tanda-tanda bahaya kehamila. Tujuan dari penelitian ini adalah untuk mengetahui pengaruh kelas ibu hamil terhadap tingkat pengetahuan ibu hamil tentang tanda bahaya kehamilan di wilayah kerja Puskesmas Banyumulek Tahun 2018.

Desain dalam penelitian ini adalah analitik dengan rancangan bersifat cross sectional. Populasi dalam penelitian ini adalah semua ibu hamil yang mengikuti kelas ibu hamil di wilayah kerja Puskesmas Banyumulek pada bulan Januari sampai bulan Mei 2018 yaitu sebanyak 200 orang ibu hamil.Tekhnik pengambilan sampel dalam penelitian ini adalah purposive sampling sehingga sampel dalam penelitian ini adalah sebagian ibu hamil yang pernah mengikuti kelas ibu hamil di wilayah kerja puskesmas banyumulek sebanyak 67 responden. Alat bantu yang digunakan adalah kuesioner.

Analisa data menggunakan uji Chi-Square dengan taraf signifikansi a 0,05. Hasil penelitian berdasarkan Tingkat pengetahuan menunjukkan bahwa 46 responden berada pada kategori tingkat pengetahuan baik $(68,7 \%)$, sebanyak 17 responden berada pada tingkat pengetahuan cukup $(25,4 \%)$ dan sebanyak 4 responden berada pada tingkat pengetahuan kurang (6,0\%).Dari hasil analisis statistic dengan menggunakan uji Chi-Square diperoleh hasil nilai $\mathrm{p}=0,000(\mathrm{p}<0,05)$ artinya Ho ditolak dan Ho diterima dengan demikian dapa dibuat kesimpulan bahwa kelas ibu hamil berpengaruh terhadap tingkat pengetahuan ibu hamil tentang tanda bahaya kehamilan.
\end{abstract}

Kata kunci : Ibu Hamil, Tingkat Pengetahuan, Bahaya Kehamilan

\section{Pendahuluan}

Menurut laporan WHO tahun 2014 Angka Kematian Ibu (AKI) sangat tinggi di dunia, tercatat 800 perempuan meninggal setiap hari akibat komplikasi kehamilan, proses kelahiran dan aborsi yang tidak aman. Sekitar satu perempuan meninggal setiap menit (WHO,2011).

Berdasarkan Survey DemografiKesehatan Indonesia (SDKI) padatahun 2012, AKI di Indonesia adalah 262/100.000 kelahiranhidup, sedangkan AKB yaitu 32/1000 kelahiranhidup. Penyebab AKI diantaranyaPerdarahan $\quad(58,1 \%)$, preeklampsi/eklampsi (15,9\%), infeksi (9\%), komplikasimasapuerperium (4\%), abortus (3\%), partus lama (3\%), emboli obstetri (2\%), dan lain-lain (5\%) (Depkes RI, 2012).

Data dari Dinas Kesehatan Provinsi NTB menyebutkan jumlah kematian ibu pada tahun 2010 sebanyak 113 kasus dan mengalami peningkatan pada tahun 2017yaitu sebanyak 130 kasus.

Berdasarkan hasil PWS KIA Lombok Barat 2017, sasaran ibu hamil 1670 jiwa, ibu bersalin 1.196 jiwa dan bayi 1.040 jiwa.Menurut Laporan Dinas Kesehatan Kabupaten Lombok Barat kasus kematian ibu 2 tahun terakhir mengalami penurunan.
Pada tahun 2015 sampai dengan tahun 2017 tidak ditemukan kematian ibu.

Berdasarkan hasil PWS KIA Puskesmas Banyumulek pada akhir tahun 2017, jumlah sasaran ibu hamil 498 jiwa.Data dari Puskesmas Banyumulek pada tahun 2016 sampai dengan tahun 2018 tidak ditemukan kematian ibu.

Menurut Notoatmodjo (2010), pengetahuan seseorang terhadap objek mempunyai intensitas atau tingkat berbeda-beda. Secara garis besarnya dibagi dalam 6 tingkat pengetahuan, yaitu Tahu (know), Memahami (Comperhension), Aplikasi (Aplication), Analisis (Analysis), Sintesis (Synthesis) danEvaluasi.

Tanda-tanda bahaya kehamilan adalah komplikasi yang dapat dialami ibu hamil selama kehamilan (SitiBandiyah, 2014).

Kegiatan Kelas Ibu Hamil merupakan sarana untuk belajar kelompok tentang kesehatan bagi ibu hamil, dalam bentuk tatap muka yang bertujuan meningkatkan pengetahuan dan keterampilan ibuibu mengenai kehamilan, persalinan, perawatan nifas dan perawatan bayi baru lahir, melalui praktik dengan menggunakan buku KIA (Depkes, 2009).

Berdasarkan data 3 tahun terakhir dari puskesmas Banyumulek jumlah ibu hamil yang mengikuti kelas ibu hamil di Wilayah kerja 
Puskesmas Banyumulek yaitu pada tahun 2016 sebanyak 240 orang, mengalami penurunan padatahun 2017 sebanyak 200 orang dan padatahun 2018 jumlahnya tetap yaitu 200 orang.

Berdasarkan pengamatan sementara bahwa peneliti telah melakukan pengamatan di puskesmas banyumulek. Dari 10 ibu hamil yang memeriksa kehamilannya hanya 4 orang yang mengetahui tanda-tanda bahaya kehamilan, peneliti menyimpulkan bahwa masih banyak ibu hamil yang belum mengetahui tanda-tanda bahaya kehamilan sehingga peneliti tertarik untuk meneliti tingkat pengetahuan ibu hamil tentang tanda-tanda bahaya kehamilan.

Menurut hasil penelitian oleh Fanindar Nur Isdiaty dengan judul Pengetahuan Tanda Bahaya Kehamilan dan Perilaku Perawatan Kehamilan pada Ibu Hamil Trimester III tahun 2014. Didapatkan hasil tidak ada hubungan yang signifikan secara statistic antara pengetahuan tanda bahaya dengan perilaku perawatan kehamilan pada ibu hamil trimester III.

Menurut hasil penelitian oleh Anita dengan judul Pengaruh Promosi Kesehatan Tentang Tanda Bahaya Kehamilan Terhadap Pengetahuan Ibu Hamil di Puskesmas Amurang Kabupaten Minahasa Selatan tahun 2013. Didapatkan hasil ada peningkatan pengetahuan ibu-ibu hamil di Puskesmas Amurang dari cukup pada pre test $(74,3 \%)$ menjadi baik $(80 \%)$ pada post test.

Menurut hasil penelitian oleh Uswatun Hasanah dengan judul Hubungan Pengetahuan Ibu Hamil tentang Kelas Ibu Hamil dengan motivasi mengikuti Kelas Ibu Hamil di Puskesmas 2 Mandiraja Kabupaten Banjanegara tahun 2012. Didapatkan hasil Motivasi ibu hamil mengikuti kelas ibu hamil di Wilayah kerja Puskesmas 2 Mandiraja Kabupaten Banjanegara Tahun 2012 paling banyak mempunyai motivasi baik sebanyak 2 orang dari 76 ibu hamil.

Dari latar belakang diatas, dapat dirumuskan masalah sebagai berikut:

"Apakah Kelas Ibu Hamil Berpengaruh Terhadap Tingkat Pengetahuan Ibu Hamil Tentang Tanda Bahaya Kehamilan di Wilayah Kerja Puskesmas Banyumulek Tahun 2018?"

\section{Metode Penelitian}

\section{a. Jumlah Sampel}

Besar sampel dalam penelitian ini dihitung dengan menggunakan rumus dari (Notoatmodjo, 2005).

$\mathrm{n}=\frac{\mathrm{N}}{1+\mathrm{N}(\mathrm{d})^{2}}$

$\mathrm{N}$ : banyaknya populasi

d : tingkat kepercayaan $(0,1)$
Sampel

$$
\begin{aligned}
\mathrm{n} & =\frac{200}{1+200(0,1)^{2}} \\
\mathrm{n} & =200 \\
& =67
\end{aligned}
$$

Jadi banyaknya sampel 67 ibu hamil.

\section{b. Analisa Data}

\section{Analisis Univariat}

Analisa data yang digunakan dalam penelitian adalah Analisa Univariat yaitu analisa yang digunakan untuk mendeskripsikan atau menggambarkan karakteristik tiap variabel dari hasil tiap penelitian utnuk menghasilkan distribusi frekuensi dan persentase dari tiap variabel. (Notoatmodjo, 2012). Variabel yang dianalisa secara univariat meliputi pengetahuan. Untuk mengetahui tingkat pengetahuan dihitung dengan menggunakan tabel distribusi frekuensi dalam bentuk gambaran pengetahuan. Sedangkan untuk mengetahui masingmasing kriteria tingkat pengetahuan dengan menggunakan rumus :

$\mathrm{P}=\frac{\mathrm{F}}{\mathrm{N}} \times 100 \%$

Keterangan :

$\begin{array}{lll}\mathrm{P} & : & \text { Presentase } \\ \mathrm{F} & : & \text { Jumlah jawaban benar } \\ \mathrm{N} & : & \text { Jumlah total pertanyaan } \\ 100 \% & : & \text { Bilangan tetap }\end{array}$

Setelah presentase diketahui dimasukkan ke dalam kategori menurut Arikunto (2006).

\section{Analisis Bivariat}

Analisa Bivariat yang dilakukan terhadap dua variabel yang di duga berhubungan atau berkorelasi. Dalam penelitian ini untuk mengetahui lebih lanjut pengaruh kelas ibu hamil terhadap Analisa Bivariat yang dilakukan terhadap dua variabel yang di duga tingkat pengetahuan ibu hamil tentang tanda bahaya kehamilan.Untuk membuktikan ada tidaknya hubungan tersebut, dilakukan statistik uji Chi-square dengan derajat kepercayaan 95\% $(\alpha=0,05)$. Dalam penelitian ini pengolahan data menggunakan program software pengolahan data statistik, yang nantinya akan diperoleh nilai $p$. Nilai $p$ akan dibandingkan dengan nilai $\alpha$. Dengan ketentuan sebagai berikut.

a. Jika nilai $\mathrm{p} \leq \alpha(\mathrm{p} \leq 0,05)$. Maka hipotesis $\left(\mathrm{H}_{0}\right)$ ditolak, berarti data sampel mendukung adanya perbedaan yang signifikan.

b. Jika nilai $>\alpha(\mathrm{p}>0,05)$. Maka hipotesis $\left(\mathrm{H}_{0}\right)$ diterima, berarti sampel tidak mendukung adanya perubahan yang bermakna. 


\section{Hasil dan Pembahasan}

a. Identifikasi distribusi frekuensi responden berdasarkan jumlah ibu hamil yang sudah melakukan kelas ibu hamil

\begin{tabular}{|c|c|c|c|}
\hline \multirow{2}{*}{ No. } & \multirow{2}{*}{$\begin{array}{c}\text { Kelas ibu } \\
\text { hamil }\end{array}$} & \multicolumn{2}{|c|}{ Jumlah } \\
\hline & & $\mathbf{N}$ & $\%$ \\
\hline 1 & $\begin{array}{c}\text { Sesuai standar } \\
\text { kunjungan }\end{array}$ & 50 & 74,6 \\
\hline 2 & $\begin{array}{c}\text { Tidak sesuai } \\
\text { standar } \\
\text { kunjungan }\end{array}$ & 17 & 25,4 \\
\hline & Total & 67 & 100,0 \\
\hline
\end{tabular}

Berdasarkan table diatas dapat dilihat dari 67 orang responden sebagian besar yang mengikuti kelas ibu hamil sesuai standar kunjungan yaitu sebanyak 50 responden $(74,6 \%)$ dan yang mengikuti kelas ibu hamil tidak sesuai standar kunjungan yaitu sebanyak 17 responden $(25,4 \%)$.

hasil penelitian menunjukkan bahwa dari 67 responden diperoleh sebanyak 50 responden $(74,6 \%)$ mengikuti kelas ibu hamil sebanyak $\geq 4$ kali dan 17 responden $(25,4 \%)$ mengikuti kelas ibu hamil sebanyak <4 kali. Hal ini menunjukkan bahwa sebagian besar ibu hamil mengikuti kelas ibu hamil sebanyak $\geq 4$ kali sehingga mendukung bertambahnya pengetahuan ibu hamil terhadap tanda bahaya kehamilan. Namun masih ada beberapa responden yang mengikuti kelas ibu hamil tidak sesuai dengan standar yaitu karena mereka lebih mementingkan pekerjaan Ibu Rumah Tangga seperti memasak, menyuci atau mengurus anak dari pada mengikuti kelas ibu hamil.

Hasil penelitian tersebut didukung oleh penelitian dilakukan oleh Sasnitiari Ni N dan kawankawan (2017) yang dilakukan di kota Bogor Jawa Barat dari hasil penelitian ini responden yang mengikuti kelas ibu hamil 2 kali atau lebih sebanyak $56,3 \%$ pengetahuan responden tentang tanda bahaya kehamilan sebagian besar baik, yaitusebesar 79,1\% dan sikap responden terhadap tanda bahaya kehamilan sebagian besar positif yaitu sebesar 66,7 $\%$. Sehingga dapat disimpulkan bahwa peran kelas ibu hamil dapat meningkatkan pengetahuan tentang tanda bahaya kehamilan, makas etiap kelas program kelas ibu hamil yang berjalan akan berkontribusi terhadap upaya penurunan AKI dan AKBA.

Hal tersebut dapat juga dikaitkan dengan teori yang menyatakan bahwa Kelas Ibu Hamil merupakan sarana untuk belajar kelompok tentang kesehatan bagi ibu hamil, dalam bentuk tatap muka yang bertujuan meningkatkan pengetahuan dan keterampilan ibu-ibumengenaikehamilan, persalinan, perawatan nifas dan perawatan bayi baru lahir, melalui praktik dengan menggunakan buku KIA (Kesehatan Ibu dan Anak) (Depkes, 2009 : vii)

Hasil penelitian uji coba yang dilaksanakan oleh Japan Internatianal Coorperation Agency
(JICA) bekerja sama dengan Departemen Kesehatan Republik Indonesia padatahun 2008 di daerah Nusa Tenggara Barat menemukan terdapat peningkatan pengetahuan sikap dan perilaku positif dalam menghadapi kehamilan, persalinan dan masa nifas pada ibu hamil yang megikuti kelas ibu hamil (Ariyani 2012).

\section{b. Identifikasi distribusi frekuensi responden berdasarkan tingkat pengetahuan ibu hamil tentang tanda bahaya kehamilan}

Setelah dilakukan penelitian diperoleh hasil seperti table dibawah ini :

\begin{tabular}{|c|c|c|c|}
\hline & Tingkat & \multicolumn{2}{|c|}{ Jumlah } \\
\cline { 3 - 4 } No. & $\begin{array}{c}\text { pengetahuan ibu } \\
\text { hamil tentang } \\
\text { tanda bahaya } \\
\text { kehamilan }\end{array}$ & $\mathbf{N}$ & $\%$ \\
\hline 1. & Baik & 46 & 68,7 \\
\hline 2 & Cukup & 17 & 25,4 \\
\hline 3 & Kurang & 4 & 6,0 \\
\hline & Total & $\mathbf{6 7}$ & $\mathbf{1 0 0 , 0}$ \\
\hline
\end{tabular}

Berdasarkan table diatas dapat dilihat dari 67
orang responden sebagian besar yang
berpengetahuan baik yaitu sebanyak 46 responden
$(68,7 \%)$ dan yang berpengetahuan kurang hanya 4
responden atau $(6,0 \%)$.
Pada tabel 5.2 dari 67 responden sebagian besar responden memiliki pengetahuan yang baik tentang tanda bahaya kehamilan Berdasarkan hasil penelitian yang dilakukan oleh peneliti dari 67 responden sebagian besar yang berpengetahuan baik sebanyak 46 responden $(68,7 \%)$ dan sebanyak 4 responden $(6,0 \%)$ yang berpengetahuan kurang.

Dari keseluruhan kuisioner yang telah di jawab setelah dilakukan penelitian sebagian besar responden yang mengikuti kelas ibu hamil $\geq 4$ kali berpengetahuan baik dan responden yang mengikuti kelas ibu hamil<4 kali berpengetahuan cukup dan kurang.

Kegiatan Kelas Ibu Hamil merupakan sarana untuk belajar kelompok tentang kesehatan bagi ibu hamil, dalam bentuk tatap muka yang bertujuan meningkatkan pengetahuan dan keterampilan ibuibu mengenai kehamilan, persalinan, perawatan nifas dan perawatan bayi baru lahir, melalui praktik dengan menggunakan buku KIA (Kesehatan Ibu anak) ( Depkes, 2009 : vii).

Jika dilihat dari tujuan dilakukan kelas ibu hamil tersebut jika ibu hamil tidak mengikuti kelas ibu hamil dampak yang dapat terja di adalah ibu akan memiliki pengetahuan yang kurang tentang tanda bahaya kehamilan, persalinan, perawatan nifas dan perawatan bayi baru lahir.

Hasil penelitian ini didukung oleh penelitian yang dilakukan oleh Johanes di Indonesia dampak ibu hamil tidak mengikuti kelas ibu hamil sebesar 
$53 \%$ ibu tidak mengetahui resiko atau tanda bahaya kehamilan (Johanes 2013).

Hasil penelitian tersebut didukung oleh penelitian Monita Nathania (2015) di wilayah kerja Puskesmas Alalak Tengah Banjarmasin, didapatkan hasil sebagai berikut :

Hasil penelitian terhadap 85 orang responden ibu hamil di wilayah kerja Puskesmas Alalak Tengah didapatkan bahwa pengetauan yang dimiliki ibu hamil tentang tanda-tanda bahaya kehamilan baik terlihat dari 51 orang $(60 \%)$ responden berpengetahuan baik. Beberapa factor yang mempengaruhi adalah umur, pendidikan, pekerjaandan gravid responden.

Pengetahuan adalah sesuatu yang diketahui seseorang melalui pendidikan atau pengalaman terhadap suatu objek melalui panca indra manusia yaitu pengelihatan, penciuman, pendengaran, rasa danraba. (Notoadmojo, 2012)

Pengetahuan manusia mempunyai 6 tingkatan, yaitu tahu untuk mengetahui atau mengukur bahwa orang tau sesuatu menggunakan pertanyaan, memahami atau kemampuan untuk menjelaskan secara benar tentang objek yang diketahui dan dapat menginterpretasikan secara benar tentang objek yang diketahui, Aplikasi, Analisis, Sintesis, serta Evaluasi.

Faktor - fackor yang mempengaruhi pengetahuan adalah faktor internal yaitu pendidikan, usia, pengalaman, kepribadian. Faktor eksternal yaitu lingkungan, informasi, budaya dan social ekonomi. Dalam penelitian ini salah satu faktor yang mempengaruhi pengetahuan ibu adalah kurangnya informasi yang mereka dapatkan baik dari lingkungan rumah dan sekitarnya meliputi suami, orang tua, tetangga dan tenaga kesehatan.

Cara memproleh pengetahuan dapat dikelompokkan menjadi dua, cara tradisional yaitu berdasarkan cara coba salah, cara kekuasaan, pengalaman pribadi dan melalui jalan pikiran. Serta secara modern atau cara ilmiah yaitu upaya memecahkan masalah melalui berfikir rasional dan berfikir empiris. (Notoadmojo, 2012).

\section{c. Analisis pengaruh kelas ibu hamil terhadap tingkat pengetahuan ibu hamil tentang tanda bahaya kehamilan}

Setelah dilakukan penelitian diperoleh hasil seperti tabel dibawah ini :

\begin{tabular}{|c|c|c|c|c|c|c|c|c|c|c|}
\hline \multirow{3}{*}{ No } & \multirow{3}{*}{ Kelas Ibu Hamil } & \multicolumn{6}{|c|}{$\begin{array}{c}\text { Tingkat Pengetahuan Ibu Hamil } \\
\text { Tentang Tanda Bahaya Kehamilan }\end{array}$} & \multirow{2}{*}{\multicolumn{2}{|c|}{ Total }} & \multirow{3}{*}{$\begin{array}{c}\text { p. } \\
\text { value }\end{array}$} \\
\hline & & \multicolumn{2}{|c|}{ Baik } & \multicolumn{2}{|c|}{ Cukup } & \multicolumn{2}{|c|}{ Kurang } & & & \\
\hline & & $\mathbf{N}$ & $\%$ & $\mathbf{N}$ & $\%$ & $\mathbf{N}$ & $\%$ & $\mathbf{N}$ & $\%$ & \\
\hline 1 & $\begin{array}{l}\text { Sesuai Standar } \\
\text { Kunjungan }\end{array}$ & 45 & 90,0 & 5 & 10,0 & 0 & 0 & 50 & 100,0 & תחת \\
\hline 2 & $\begin{array}{l}\text { Tidak Sesuai Standar } \\
\text { Kunjungan }\end{array}$ & 1 & 5,9 & 12 & 70,0 & 4 & 23,5 & 17 & 100,0 & 0,000 \\
\hline
\end{tabular}

Berdasarkan table diatas jumlah ibu hamil yang mengikuti kelas ibu hamil sesuai dengan standar kunjungan sebanyak 50 responden $(74,6 \%)$ yang paling banyak yaitu yang berpengetahuan baik berjumlah 45 responden $(90,0 \%)$, sedangkan jumlah ibu hamil yang mengikuti kelas ibu hamil tidak sesuai standar kunjungan sebanyak 17 responden $(25,4 \%)$ yang paling banyak yaitu yang berpengetahuan cukup berjumlah 12 responden $(70,6 \%)$.

Sedangkan dari hasil analisis statistic dengan mempergunakan uji Chi-Square diperoleh hasil nilai $\rho$ value $=0,000(\rho<0,05)$ artinya Ho ditolak dan $\mathrm{Ha}$ diterima. Dengan demikian dapat dibuat kesimpulan bahwa kelas ibu hamil berpengaruh terhadap tingkat pengetahuan ibu hamil tentang tanda bahaya kehamilan.

\section{d. Pengaruh Kelas Ibu Hamil terhadap Tingkat Pengetahuan Ibu Hamil Tentang Tanda Bahaya Kehamilan}

Dari hasil analisis statistic dengan mempergunakan Uji Chi-Square diperoleh hasil nilai $\rho$ value $=0,000(\rho<0,05)$ artinya Ho ditolak dan $\mathrm{Ha}$ diterima. Dengan demikian dapat dibuat kesimpulan bahwa kelas ibu hamil berpengaruh terhadap tingkat pengetahuan ibu hamil tentang tanda bahaya kehamilan. Terdapat perbedaan tingkat pengetahuan ibu hamil yang mengikuti kelas ibu hamil $\geq 4$ kali dengan yang mengikuti kelas ibu hamil $<4$ kali, ibu hamil yang mengikuti kelas ibu hamil $\geq 4$ kali berpengetahuan baik sedangkan ibu hamil yang mengikuti kelas ibu hamil <4 kali ada yang berpengetahuan cukup dan kurang. Perbedaan ini bisa disebabkan oleh beberapa faktor yang mempengaruhi pengetahuann yaitu pendidikan, usia, pengalaman, lingkungan, informasi, dansosialekonomi.

Kelas ibu hamil merupakan sarana untuk belajar kelompok tentang kesehatan bagi ibu hamil, karena dengan mengikuti kelas ibu hamil yang sesuai dengan standar kunjungan yaitu $\geq 4$ kali dapat meningkatkan pengetahuan dan keterampilan ibu mengenai kehamilan, persalinan, perawaan nifas dan perawatan bayi baru lahir menggunakan buku KIA (Kesehatan Ibu Anak) (Depkes, 2009 : vii).

Pada penelitian Sasnitiari Ni N dan kawankawan ( 2017), hasil analisa bivariat menunjukkan bahwa terdapat hubungan yang bermakna antara keikutsertaan ibu dalam mengikuti kelas ibu hamil dengan pengetahuan ibu tentang tanda bahaya 
kehamilan hal ini menunjukkan bahwa ibu hamil yang mengikuti kelas ibu hamil $\geq 4$ kali mempunyai pengetahuan baik terhadap tanda bahaya kehamilan sebanyak 87\%. Artinya semakin sering ibu mendapatkan informasi maka akan meningkatkan keingin tahuan ibu tentang tanda bahaya kehamilan. Hasil penelitian ini menguatkan bahwa keikutsertaan kelas ibu hamil berperan dalam meningkatkan pengetahuan tentang tanda bahaya kehamilan dan sikap respon ibu hamil terhadap bahaya kehamilan.

\section{Kesimpulan}

1. Dari 67 orang responden yang mengikuti kelas ibu hamil, sebagian besar responden mengikuti kelas ibu hamil sesuai standar kunjungan yaitu sebanyak 50 responden $(74,6 \%)$ dan yang mengikuti kelas ibu hamil tidak sesuai standar kunjungan yaitu sebanyak 17 responden $(25,4 \%)$.

2. Dari 67 orang responden sebagian besar yang berpengetahuan baik yaitu sebanyak 46 responden $(68,7 \%)$ dan yang berpengetahuan kurang hanya 4 responden $(6,0 \%)$.

3. Dari hasil analisis statistik dengan mempergunakan Uji Chi-Square diperoleh hasil nilai $\rho$ value $=0,000(\rho<0,05)$ artinya Ho ditolak dan Ha diterima. Dengan demikian dapat dibuat kesimpulan bahwa kelas ibu hamil berpengaruh terhadap tingkat pengetahuan ibu hamil tentang tanda bahaya kehamilan.

\section{Daftar Pustaka}

Akademi Kebidanan Sari Mulia 2012. Pedoman Penulisa Karya Tulis Ilmiah. Banjarmasin.

Arikunto. 2006. Prosedur Penelitian. Rineka Cipta: Jakarta.

Arikunto. 2010. Prosedur Penelitian. Rineka Cipta: Jakarta.

Ariyani 2012. Kelas Ibu Hamil

Data Puskesmas Banyumulek tahun 2017.

Depkes, 2009 :vii.Kesehatan Ibu Dan Anak

Depkes, 2009.Pedoman Pelaksanaan Kelas Ibu Hamil. Jakarta

Ihsan, 2008. Faktor-faktor Yang Mempengaruhi Pengetahuan, Jakarta: Pustaka Sinar. Harapan

Manuaba, dkk. 2007. Pembagian Paritas. Penerbit Buku Kedokteran EGC. Jakarta

Manuaba, dkk. 2010. Tanda Dan Gejala Kehamilan. Penerbit Buku Kedokteran EGC. Jakarta

Mochtar, 2011.Penyebab Keguguran Pada Ibu Hamil. Yogyakarta 